\section{THE BUILDING OF THE ALPS 1}

WHEN were the Alps upraised, and what is the age of their building stones? On the former of these questions there is less diversity of opinion than on the latter; yet, notwithstanding all that has been written on both, I am not without hope that I may find a few things sufficiently novel to be of interest to a general audience.

The subject, indeed, is so vast that I must crave your indulgence for leaving some gaps in my reasoning unfilled, and presenting you with little more than an outline. To save time I shall assume a knowledge of the simpler geological terms, asking you only to remember that I always use the word "schist," as I maintain it ought to be used, to denote a more or less fissile rock the constituents of which have undergone so much mineral change that, as a rule, their original nature is almost wholly a matter of conjecture. I must also ask you to remember that, though I have seldom mentioned the names of other workers, I am really doing little more than giving an epitome of the labours of a host of geologists, conspicuous among whom are Heim, Baltzer, Von Hauer, Gastaldi, Lory, Favre, Renevier, and many more, both Continental and English ; I select, however, those facts with which I have myself become familiar during many visits to different districts of the Alps, from the Viso on the south to the Dachstein on the east.

It is needless, I assume, to explain that mountain chains are the result of lateral thrust rather than of vertical upheaval, and their contours are mainly due to the sculpturing action of heat and frost, rain and rivers, acting upon rocks bent into various positions, and of various degrees of destructibility. There are, however, three principles which are less familiar, but which I must ask you to bear in mind throughout this lecture: (I) that when a true schist is asserted to be the metamorphosed representative of a post-Archrean rock, the onus probandi lies with him who makes the assertion; (2) that rocks composed of the detritus of older rocks may often readily be mistaken for them; (3) that great caution is needed in applying the principles of lowland stratigraphy to a mountain region. The first of these is, I know, disputed, but there can be little doubt as to its accuracy; the second is indisputable, so is the third; but I will briefly illustrate what I mean by the statement. [Attention was then directed to diagrams of folds and reversals of strata in the Alps.]

The first section to which I invite your attention is in the neighbourhood of the Lake of Lucerne. There are fow travellers to whom the cliffs of the Rigi are not familiar. Those great walls of rock, along and beneath which the Rigibahn now takes its audacious way, are mainly composed of cnormous masses of conglomerate, an indurated gravel of Miocene age, called the nagelflue. These pebble beds may be traced in greater or less development along the north-western margin of the Swiss Alps; they attain in the Rigi and the fatal crags of the adjoining Rossberg a thickness of not less than 2000 feet. The structure and nature of this nagelflue show that it has been deposited by rivers, possibly at their entry into lakes, but more probably, as suggested by my friend Mr. Blanford, on beginning a lowland course at the very gates of the mountains. In this great mass there are indeed pebbles of doubtful derivation; but we need not hesitate to refer the bulk of them to the mountains which lie towards the east, and we may regard the great pebble beds of the Rigi and the Rossberg as built of the ruins of Miocene Alps by the streams of a Miocene Reuss. Now when we scrutinise the pebbles of this nagelflue we are at once struck by a remarkable fact. The Reuss, at the present day, only passes through Mesozoic rocks when it approaches the neighbourhood of the Lake of Lucerne. It is within the mark to say that quite three-fourth of its drainage area consists of crystalline rocks. Hence schists and gneisses abound among its pebbles, and the same rocks are no less frequent among the erratics which have been deposited by the vanished glaciers of the Great Ice Age on the flanks of the Rigi to a height of 2000 feet above the Lake of Lucerne. Yet, on examining the nagelflue, we find that, while pebbles of grit, and limestone, and chert-specimens of the Alpine Mesozoic rocks-abound, pebbles of schist and gneiss are extremely rare. I had searched for hours before I found a single one. The matrix also of the nagelflue - the mortar which makes this natural concrete-when examined beneath the microscope, tells the same story. We do not see in it the frequent quartz grains, the occa-

${ }^{x}$ Lecture by Prof. T. G. Bonney, D.Sc., F.R.S., Pres. G.S., at the Royal Institution, April 4 . sional pieces of felspar, the mica flakes, which are records of the detrition of gneissic rocks, but it consists of fragments similar to those which form the larger pebbles. It is therefore a legitimate inference that, in this part of the Alps at least, the protective covering of Mesozoic rock in the Miocene age had not generally been stripped away from the crystalline schists of the Upper Reuss, and that since then the mountains may have been diminished and the valleys deepened by at least a mile vertically. I have spoken only of the valley of the Reuss, but a little consideration will show that my remarks may be extended to a much larger area of the Oberland Alps.

I pass now to two other sections: of these the first is in the neighbourhood of Pontresina. Most of the peaks in this region consist of igneous rocks, of gneisses, and of schists, but some of later date are not wanting - as, for example, may be seen in the flanks of the well-known Heuthal. These last are limestones of Triassic age. Here they overlie unconformably a coarse gneiss -in other places they rest on schists presumably of later date ; in fact, the series of Mesozoic rocks of which the above limestone is the lowest member-though now to a great extent removed by denudation-has clearly once passed transgressively over the whole series of gneisses and schists of the Engadine.

The second section, or rather group of sections, is some distance away to the south-east, in the region of the Italian Tyrol. Those magnificent crags of the Dolomite mountains, the serrate teeth of the Rosengarten and the Langkofel, the towers of the Cristallo and the Drei Zinnen, the precipitous masses of the Blattkogel and the Marmolata, are built up of rocks of Triassic age, not of a very different date from the soft red marls which occupy so large an area in the Midlands of England. Follow me for one moment by the mountain road from Predazzo to Primiero. At the former place-classic ground for geologists -we are surrounded by great masses of igneous rocks, the roots, it may be, of long-vanished cones, although we refuse to recognise a crater in the valley about Predazzo. As we ascend toward. the beautiful Alps of Paneveggio, we pass for a considerable distance over a great mass of red felstone. This belongs to a group of igneous rocks which extend to the westward even beyond the Etsch. It is overlain by the beds of the Trias, commencing with the red Grodner sandstone and passing up soon into the vast masses of clolomite which form the wild crags of the Cimon della Pala and its attendant summits. But as we descend on the other side of the pass towards Primiero, we see the Triassic rocks, without the intervention of the felstone, resting upon mica schists, similar to those which occur in many other parts of the Alps. Sections of the above kind, were it needful, might be multiplied indefinitely to prove that between the base of the Trias and the Alpine schists and gneisses there is an enormous break, but we may content ourselves with one other, interesting not only for the completeness of the demonstration, but also for the mode in which it illustrates Alpine structure. [Attention was then directed to the section of the Mont Blanc range as given by Prof. Favre.]

The Aiguilles Rouges are composed of coarse gneisses and crystalline schists, but on the highest summit there remains a fragmental outlier of stratified and unaltered rock. The upper part of this is certainly Jurassic. Below this comes a representative of the Trias-much attenuated, as it is generally in this western region, with possibly a remnant of a deposit of Carboniferous age. Be that as it may, there is undoubtedly here a great break between the crystalline series and the succeeding Mesozoic or Palæozoic rock.

There remains yet one other section to which I wish to direct your attention; it is near Vernayaz, in the vicinity of the famous gorge of the Trient. Where the Rhone bends, at Martigny, from a south-west to a north-west course, the crystalline massif of the Mont Blanc region of which we have just spoken crosses the river, and is lost to sight as it plunges beneath the Mesozoic rocks of the western summits of the Oberland. The gorge of the Trient is cut through hard and moderately coarse gneiss the same rock occurs at the Sallenche waterfall. Between the two is a mass of rock of a totally different character-in part a dark slate, like some in Britain of Lower Silurian age; in part a conglomerate or breccia in a micaceous matrix, proved by its plant remains to be a member of the Carboniferous series. Omitting some minor details, not without interest, it may suffice to say that we have in this place the end of an almost vertical loop, formed by the folding of beds of Carboniferous age between the crystalline rocks, which are the foundation-stones of the district. The conglomerate is at the base of the Carboniferous 
series, and its matrix so closely resembles a mica schist that it has been claimed as indicating metamorphism, and as linking together the Carboniferous slates and the crystalline schists. But, in the first place, the fragments in the conglomerate are not only gneisses and schists, but also ordinary slaty rocks, no more altered than those of Llanberis. How, we may well ask, could the latter escape unchanged when all the surrounding matrix was converted into mica schist? Further, when we apply the test of the microscope--that Ithuriel spear by which the deceits of rocks are so often revealed-we find that this seeming mica schist is only the consolidated debris of micaceous rocis. Its composition, and that of the conglomerate, justifies us in asserting that when the Carboniferous rocks of the Valorsine were deposited there were land surfaces of gneiss and schist in the western region of the Alps, and that these rocks were substantially identical with those through which the Trient has sawn its ravine.

It would be easy to multiply instances similar to one or the other of those quoted above for this or that district of the Alpine region, from the south of Monte Viso to the north of the Adriatic, to speak only of those districts of which I have a personal knowledge; but I should speedily weary you, and will ask you to regard these as typical cases, single samples of a great collection. They justify, as I think you will agree, the following inferences:-(I) That there has been one epoch, at least, of mountain-making posterior to the deposition of the Miocene nagelflue, which has given to many parts of the Alpine chain an unlift sometimes not less than a mile in vertical elevation; (2) that prior to this there was an earlier epoch of mountain-making, which affected all the rocks of older date, including at any rate a portion of middle Eocene age-for we find marine strata of this date crowning the summit of the Diablerets, now more than I0,000 feet above the sea, and bent back, as at the Rigi Scheireck, over the beds of the nagelflue; (3) that there was a preTriassic land surface of great extent, largely composed of crystalline rocks, and that with this geological age commenced a lon continuous period of depression, lasting into Tertiary times (4) that a land surface of considerable extent existed at a yet earlier period, and that this in the Carboniferous age was watered by streams and clothed with vegetation-whether there were mountains then it is impossible to say, but the evidence certainly points to the conclusion that the ground was hilly; (5) that anterior to the last-named period there is a great gap in our records; the older rocks, whose stratigraphical position can be ascertained, being much metamorphosed, so that we appear justified in concluding that all the more important mineral changes which they had undergone occurred in pre-Carboniferous times-that is, that the later Palrozoic land surfaces consisted of gneiss and schists in all important respects identical with those which now exist.

I have thus led you step by step-by processes, I trust, of cautious induction - to the result that the Alps, as an irregular land surface, are a very ancient feature in the contour of the earth, and that the gneisses and crystalline schists, whereof they so largely consist, are rocks of very great antiquity. Let us now attempt to advance a step further by attacking the problem from another side. Hitherto we have been working downwards from the newer to the older, from the rocks of known towards those of unknown date. Beginning now in the unknown, beginning with the most remote that we can find, let us proceed onwards toward the more recent and more recognised.

This is a task of no slight difficulty. The ordinary rules of stratigraphical inference frequently fail us; nay, if blindly followed, would lead us to the most erroneous conclusions. In the apparent succession of strata in a mountain range the last may be first and the first last in the literal sense of the words. Beds may be repeated again and again by great folds, now in the direct, now in the inverse, order of their superposition. They may have been faulted and then folded, or folded and then faulted, and the difficulty is augmented by the vast scale on which these earth movements have taken place, by the frequent impossibility of scaling the crags or pinnacles where critical sections are disclosed, and by the masking of large areas of surface by snow and glacier, or by debris and vegetation. Yet more, the consciousness of these difficulties produces in the mind- I speak for myself-a sort of hesitation and scepticism, which are most unfavourable for inductive reasoning. Knowing not what features are of importance, one is perplexed by the variety of facts that seem to call for notice; knowing how easily one may be deceived, one hesitates to draw conclusions. I am often painfully conscious of how much I have lost in a previous journey from not having remarked some fact to which a fortunate accident has just compelled my attention. In this part, therefore, I must be pardoned if I speak with considerable hesitation and do not attempt more than state those inferences which seem to me warranted by facts.

I shall again ask permission to conduct you to a series of typical sections, which, however, I shall describe with less minuteness.

Let us place ourselves in imagination on the great ice-field at the upper part of the Gross Aletsch Glacier-the Place de la Concorde of Nature, as it has been happily termed. We are almost hemmed in by some of the loftiest peaks of the Bernese Oberland: the Aletschhorn, the Jungfrau, the Mönch, and several others. We find the rocks which rise immediately round the glacier-as, for example, near the well-known Concordia hut -to be coarse gneisses, with difficulty distinguishable from granites. As the eye travels up to any one of the mountain ridges, the rock evidently becomes less massive and more distinctly foliated. We note the same sequence as we retrace our steps towards the Rhone valley-speaking in general terms, the ridges and the flanks of the Eggischhorn consist of more finely granulated gneisses and of strong micaceous schists, which alternate more frequently one with another. Further to the west, in the region around the Oberaletsch Glacier and on the slopes of the Bell Alp, we find the same succession-coarse granitoid gneisses in the relatively lower part of the heart of the chain, finer grained and more variable gneisses and schists on the upper ridges and the southern flanks.

Let us change our position to a spot considerably to the east, to the great section of the crystalline series made by the valley of the Reuss below Andermatt.

From the spot where the rocks close in suddenly upon the torrent near the Devil's Bridge, to a considerable distance below Wasen, extends an almost unbroken mass of coarse granitoid gneiss. This, however, becomes more distinctly bedded and schistose before it entirely disappears beneath the Secondary deposits that border the Bay of Uri. Similarly, if from Wasen, where the gneiss is barely distinguishable from granite, we ascend the wild glen which leads up to the Susten Pass; and descend on the other side by the grand scenery of the Stein Alp to the beautiful Gadmenthal, thus passing obliquely outwards along the apparent strike of the rocks to the point where, as in the neighbourhood of the Imhof, they disappear beneath Mesozoic deposits, we again find that we are among rocks which are rather more variable in their mineral character, oscillating between moderately coarse gneisses, sometimes porphyritic, and strong mica schists. Near Muhlestalden, in the Gadmenthal, even a bed of white crystalline dolomitic limestone is interstratified with the gneissic rocks

Leaving for a brief space the vicinity of the St. Gothard road, and returning to the upper valley of the Rhone, let us place ourselves on such an outlook as we can obtain from Prof. Tyndall' châlet on the Bell Alp, and fix our eyes on the magnificent panorama of the Pennine chain, with whose geology we will suppose ourselves to have become familiar in frequent traverses from the northern to the southern side of the watershed of Central Europe. Facing us, and forming the lower slopes and crags of the great mountain chain of the Pennines, we see an enormous mass of distinctly bedded rock, of a brownish tint, of which this distance we should hesitate to say whether we ought to rermi it as a member of the metamorphic or of the ordinary sedimentary series. In an east-north-east direction we see it gradually 1 ising to form the peak of the Ofenhorn and the upper part of the n ountains about the Gries Pass. In the opposite direction it forms the lower slopes of the Simplon Pass and the portals of the valley of the Visp. Hence, could we follow it, the area occupied by this rock broadens out into the spurs which inclose the Einfischthal and the Eringerthal, and crosses the watershed towards the south to the east of the St. Bernard Pass. In more than one locality in the region of the Binnenthal a band, of no great vertical thickness, of a white crystalline dolomite is conspicuously present. A very similar group of rocks occurs in the Val Piora, in some bands of which black garnets are very abundant. The same mineral also occurs in a similar rock near the summit of the Gries Pass. Anda lusite or staurolite also occurs occasionally; the group, in short, is well characterised, and for reference I will call it the Lustrous Schists. 
I pass now to the neighbourhood of the St. Gothard. The coarse gneiss, which is picrced by the northern entrance of the great tunnel, ends abruptly at the Umerloch. The basin of the Urserenthal is excavated from satiny slates, with dark limestones, very possibly of Jurassic age, and from some underlying rather variable schists. The first rock visible on the eastern side as we approach Andermatt is a schistose crystalline limestone, associated with mica schists; and a series of rather variable schists, evidently very different from the coarse gneisses of the gorge below, appears to cross the valley, and form the slopes leading to the Oberalp Pass. These may be traced for some distance up the Furka road above Realp, when they are abruptly succeeded by the slaty group mentioned above. I am convinced that they are much more ancient than the latter, being probably nembers of the Lustrous Schist group, if not older. It is obvious that the newer rocks are only a fragment of a loop of a huge fold, over which on either hand the fragments of the enveloping older metamorphic rocks tower up in mountain peaks. On the ascent of the St. Gothard Pass from Iospenthal a series of somewhat variable micaccous schists continues till the top of the first step in the ascent is reached, about 800 feet above the valley, when gneiss sets in, generally rather coarse and sometimes very porphyritic, occasionally interbanded with dark, rather friable mica schists. The upper plateau of the pass consists of a porphyritic rock, often called granite, but with a gneissose aspect and rather more friable in character than the rock of the Wasen district. On the first steep descent on the south side this rock appears to pass into a normal coarse gneiss, occasionally banded with mica schist, resembling that in a similar position on the northern flank, which is succecded for a short space by a remarkably well-banded gneiss. To this succeeds-it must be remembered that the series is inverted in order - the great group of hornblendic and garnetiferons mica schists, which continue along the Val Tremola and the lower slopes of the mountain to the neighbourhood of Airolo, where some calcareotis rock occurs, bcing probably an infold of much later date.

Through the kindness of Mr. Fletcher and Mr. Davis, of the British Museum, I have been allowed to examine the series of specimens from the St. Gothard Tunnel in that collection. They correspond in general with the succession above indicated, except that I have failed to identify the granitoid rock of the summit plateau. Leaving, however, for a moment the question of correlation, we see that the St. Gothard section presents us with an instance of folding on a gigantic scalc, and of the fan structure, doubtless with many minor flexures and faults.

In the neighbourhood of the Val Piora we get an important succession. The ascent to the hotel from the Val Berlretto passes in the main over a series of micaceous schists and rather friable gneisses, which are a prolongation of an axis exposed in the mountains south of Airolo and fairly correspond with much of the rock (excepting the granitoid) forming the upper part of the St. Gothard Pass. To this succeeds a series which, though more calcareous, clearly represents the garnetiferous actinolitic series of the southern slopes, and to this a group closely resembling the Introus Schists.

\section{(To be continied.)}

\section{UNIVERSITY AND EDUCATIONAL INTELLIGENCE}

Cambridae.-The Electors to the Professorship of Pathology will neet for the purpose of electing a Professor on May 24 . The stipend of the Professor is $800 \%$ a ycar, exclusive of fees, but he must not engage in the private practice of Medicine or Surgery.

Prof. Macalister lectures to-day on the Race Types of the Human Skull ; on Saturday, on the Race Variations of the Skin, Hair, and Soft Parts; and on Tucsday, the r3th, on the Anatomical Characters of the Prehistoric and Early Historic Races of Britain : on each day at $\mathrm{x}$ p.m.

In the Iong Vacation Prof. Macalister will take a Class in Osteology, and the Demonstrator will have a class for Practical Histology.

The new buildings for Prof. Stuart's Museum of Mechanism will be reary to receive their contents this term, and it is recommended that the buildings to provide for the Department of Botany be at once procecded with, to be ready for use at the beginning of October.

\section{SOCIETIES AND ACADEMIES LONDON}

Royal Society, May I. - "On the Connection of the Himalaya Snowfall with Dry Winds and Seasons of Drought in India." By Tenry F. Blanford, F.R.S.

In this paper the author points out that for some years past it has been suspected that the snowfall of the Himalaya has a direct influence on the dry land winds of North-Western India. The connection of the two was first noticed in 1876 and 1877 , the first-named a year of drought and famine in Southern India, the second the same in the North-Western Provinces, Rajputana, and Central India. Messrs. Hill and Archibald, about the same time, called attention to the circumstance that excessive winter rainfall in Northern India is usually followed by defective rains in the summer or monsoon season. This inference is strengthened if the rainfall of May be included in that of the winter and spring instead of in that of the summer, as is shown by a table for the eightcen years from 1864 to $188 \mathrm{I}$ inclusive. Fourteen of these years give results agreeing with Messrs. Hill and Archibald's views, and only four differ from their conclusions : two out of these four, viz. 1876 and 1880 , being found on further investigation distinctly to confirm the theory, whilst data are wanting with regard to the other two years.

After some details concerning the meteorology of the area in the years $\mathbf{1} 88 \mathrm{I}-82$, the writer gives a description of the unusual snowfall on the outer ranges of the Himalaya in the spring of 1883, and of the extensive drought in Northern, North-Western, and part of Central India that followed. In this instance a warning forecast of dry weather and retarded rainfall was published in the Gazette of India on June 2, and this forecast is shown to have been justified by the event, the rainfall in July and August over large portions of India having been much below the average.

In an account of the meteorology of the land winds it is shown that from November to February they tend to circulate anticyclonically round the axis of maximum pressure, extending from the Punjab and Sind across Rajputana and Central India towards Orissa. In March a barometric minimum is established over the Hyderabad plateau, and this extends to the north and north-east, the wind currents becoming cyclonic around the depression. To the eastward of this area some rain falls in the spring, but Western India from Belgaum to the Punjab is practically rainless from November till May, and is the dry wind area. It is then shown that the supply of air for the dry wind is derived from an upper stratum by convective interchange. After rain and snow on the Himalayas the dry winds are supplemented by an outflow of cold air from the hills accompanied by a wave of high pressure advancing eastward from the valley of the Indus.

The following summary and conclusions are given :-

(I.) The experience of recent years affords many instances of an unusually heavy and especially a late fall of snow on the North-Western Himalaya being followed by a prolonged period of drought on the plains of North-Western and Western India.

(2.) On tabulating the average rainfall of the winter and spring months at the stations of the North-Western Himalaya, year by year, for the last eighteen years, and comparing it with the average rainfall of the North-Western Provinces in the ensuing summer monsoon, it is found that with four exceptions an excessive winter precipitation on the hills is followed by a deficient summer rainfall on the plains, and vice versâ. "Of the four apparent exceptions, two are found to afford a striking support to the first proposition.

(3.) The west winds which, in Western and Northern India, are characteristic of seasons of drought as abnormal winds, are identical in character with the normal winds of the diy season, and appear to be fed by descending currents from the NorthWestern Himalaya, and possibly the western mountains generally.

(4.) It is a common and well-known phenomenon of the winter months that a fall of rain and snow on the North-Western Himalaya is immediately followed by a wave of high pressure advancing castwards from the western mountains, accompanied with dry cool north-west winds.

(5.) The conclusion is that an tnusual expanse of snow on the North-Western Himalaya, whether due to the unmelted residue of an unusually copious winter snowfall, or to an unusually late fall in the spring months, acts, at ligh levels, in the summer months, in somewhat the same way as the ordinary falls of snow and rain on the Lower IIimalaya do at low levels in the winter 